Artikel

\title{
Analysis and Design of Web-Based Project Management Information System Using Critical Path Method (CPM) Method on PT. Pakarti Tirtoagung
}

\author{
Edy ${ }^{l}$, Felina Natalia Lie ${ }^{2}$, \\ ${ }^{1,2}$ Buddhi Dharma University, Information System, Banten, Indonesian
}

\begin{tabular}{l}
\hline SUBMISSION TRACK \\
\hline Received 20 June 2019; \\
Revised 20 July 2019; \\
Accepted 10 September 2019; \\
Available online 20 September 2019 \\
KEYWORD \\
\hline
\end{tabular}

Information System, Project Management, Monitoring, CPM, Control Budgeting

KORESPONDENSI

E-mail: edy.edy@ubd.ac.id

felinanatalia624@gmail.com

\begin{abstract}
A B S T R A C T
PT. Pakarti Tirtoagung is one of the companies engaged in construction services in Indonesia, in the scope of gas and petroleum. To facilitate the company in carrying out the project implementation process and monitoring the progress of the project, a special computerized system is needed. Looking at the system that runs on the company, there is no specific system support, which has several obstacles, among others in making schedule project, errors in recording data and presenting project progress reports because project progress was not monitored, completion of projects that are not in accordance with time schedules, etc. Of the several obstacles encountered, it becomes an interesting discussion to looking for solutions that can minimize obstacles and even risks that will occur as a result of these constraints. For that it was made Analysis And Design Of Web-Based Project Management Information System Using Critical Path Method (CPM) Method On Pt. Pakarti Tirtoagung. Using the CPM method for help planning activities to project development. Based on the results of the questionnaire that was distributed to 10 (ten) respondents and after processing the results $58 \%$ of respondents felt agree and 38\% strongly agree that the system can present information about the ongoing project, monitoring the project and presenting a project progress report .
\end{abstract}

\section{INTRODUCTION}

PT. Pakarti Tirtoagung is a company engaged in construction services related to gas and petroleum. Based on the results of observations at PT. Pakarti Tirtoagung has several problems, among others project completion not according to plan, project progress has not monitored and information of project progress that not accordance with project execution resulting in the completion of the project not in accordance with the plan and cause over budgeting. Based on the problem, it was made Analysis And Design Of Web-Based Project Management Information System Using Critical Path Method (CPM) Method On Pt. Pakarti Tirtoagung. Which aims to design information system that support planning activities to project development web-based. 
And expected to provide benefits, among others the project was completed according to plan, the project planning and implementation process can be monitored, presents a report on the actual data of the project with project planning that leads to control budgeting. Using the CPM method in the process of preparing project planning that can produce information about the duration when the project starts and the project is completed, so that the project can be completed in accordance with the plan and in accordance with the specified budget. The proposed system uses a programming language Hypertext Preprocessor (PHP), javascript and uses database Structure Query Language (MySQL). This information system is expected to be able to handle problems that occur within the company and produce informatio related to project planing, project execution, and monitoring project progress to minimize the risk that can occur as a result of mismatch between plans and project execution.

\section{LITERATURES REVIEW}

Project management is all the planning, implementation, control, and coordination of a project from the beginning to the completion of the project to ensure the project is carried out on time, on cost, and on quality [1]. The main objective of project management is to manage management functions so that optimum results are obtained in accordance with established requirements and the use of resources as efficiently and effectively as possible. To achieve the objectives, it is necessary to conduct quality control, cost control, time control [2]. There is four important components from a project, scope, time, cost, and quality. necessities in a project : Completed and submitted in a timely manner; costs as specified; Scope as specified; Have the quality of results in accordance with the criteria agreed between the implementer and the project giver [4]. Web Information in the form of text is generally written in the format Hypertext Markup Language (HTML). Web can be accessed by software client Web which are called browser [5]. Dynamic websites that can be created using PHP are websites that can adjust the appearance of content depending on the situation. Dynamic websites can also store data in a database, make the page according to user input, process form, etc [6]. MySQL is database system are widely used for web application development [7]. 


\section{FRAMEWORK}

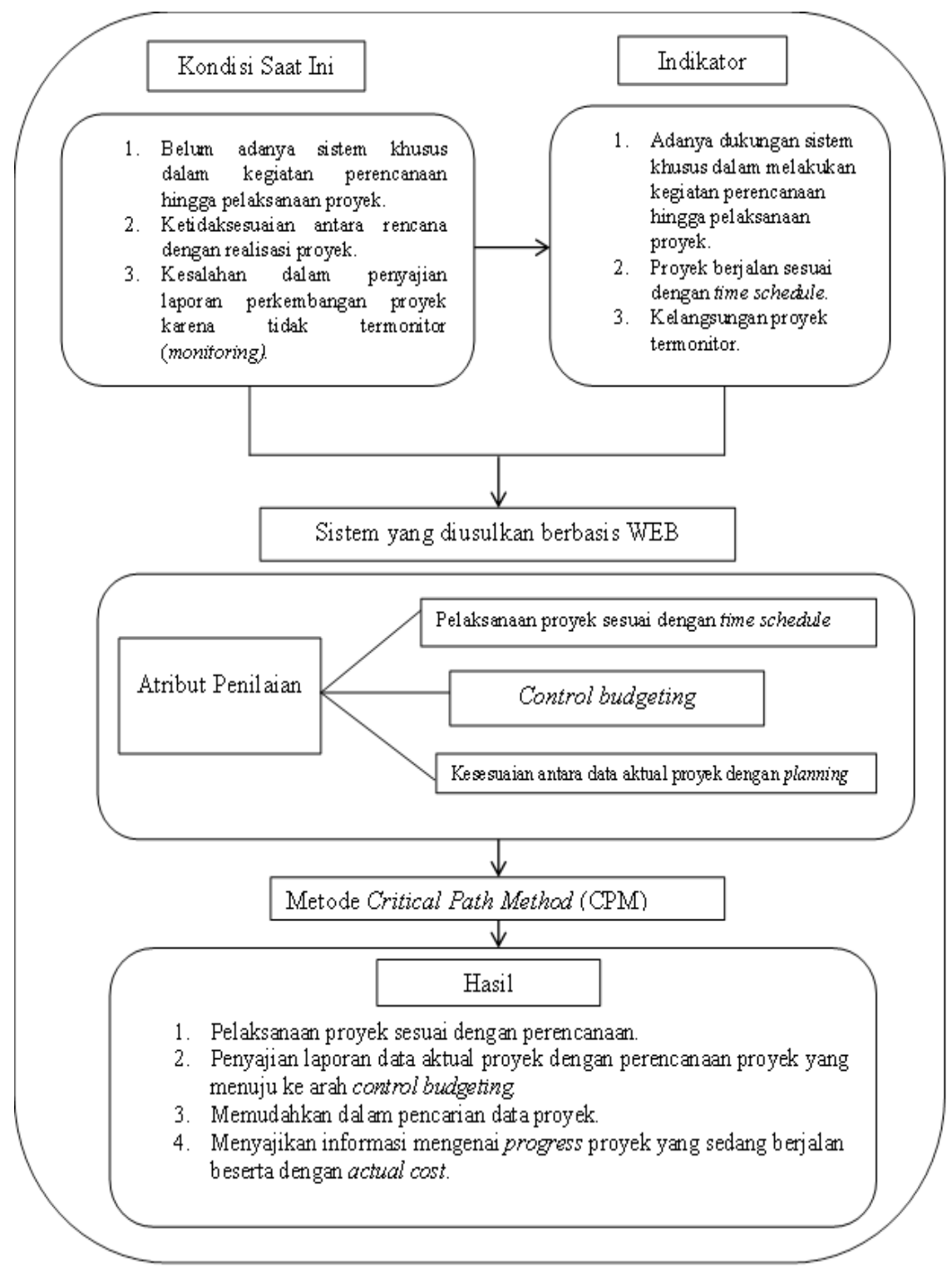

\section{METHODS}

CPM is a technique in analyzing the network of activities / activities when running a project in order to predict the total duration of project work and determine the critical path contained in a project. There are 2 stages of CPM calculation in determining the critical path [8]:

1. Forward Pass, from Start initial event to Finish terminal event to calculate the fastest completion time of an activity (EF) and the fastest time for an activity to occur (ES).

$$
E F(j)=E S(j)+\operatorname{Dur}(j)
$$

2. Backward Pass, from Finish to Start to identify at the latest the occurence of an activity (LF) and the slowest time an activity occurs (LS).

$$
L S(j)=L F(j)-\operatorname{Dur}(j)
$$

Keterangan :

1. E : Earliest event occurence time.

2. L : Latest event occurence time. 
3. ES : Earliest activity start time

4. $\mathrm{EF}$ : Earliest activity finish time

5. LS : Latest activity start time [9].

The steps in determining CPM are as follows : Divide the entire work into several occupational groups which can be said to be of the same type, Determine the duration of completion of each milestone's work, Determine the relationship between the work groups, Determine the critical path method for milestones based on the interrelationships, Compare the total duration of work with the time needed [9].

\section{CALCULATION}

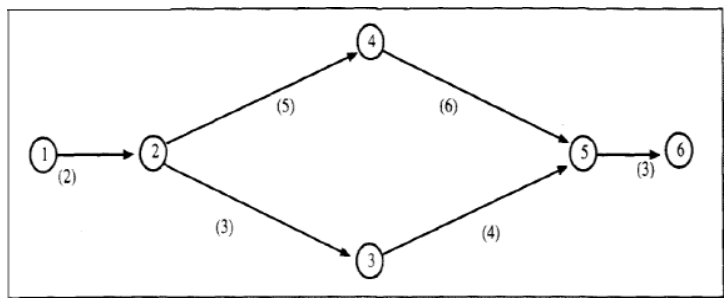

There are 6 activities and the duration of each activity has been determined.

1. Forward Pass

Table 1. Forward Pass

\begin{tabular}{|c|c|c|c|c|c|}
\hline \multicolumn{3}{|c|}{ Kegiatan } & \multirow{2}{*}{ Kurun Waktu (D) (4) } & \multicolumn{2}{|c|}{ Paling Awal } \\
\cline { 5 - 6 } $\mathrm{i}(1)$ & $\mathrm{j}(2)$ & Nama (3) & & 0 & 2 \\
\hline 1 & 2 & a & 2 & 2 & 5 \\
\hline 2 & 3 & b & 3 & 2 & 7 \\
\hline 2 & 4 & c & 5 & 5 & 9 \\
\hline 3 & 5 & d & 4 & 13 & 13 \\
\hline 4 & 5 & e & 6 & Selesai (EF) \\
\hline 5 & 6 & f & 3 & 13 \\
\hline
\end{tabular}

Based on table 1. The Count Forward explains, where 16 is the project completion time. Except for the initial activity, an activity can only begin if the preceding activity has been completed.

\section{Backward Pass}

Table 2. Backward Pass

\begin{tabular}{|c|c|c|c|c|c|c|c|}
\hline \multicolumn{3}{|c|}{ Kegiatan } & \multirow{2}{*}{ Kurun Waktu (D) (4 } & \multicolumn{2}{|c|}{ Paling Awal } & \multicolumn{2}{|c|}{ Paling Akhir } \\
\hline $\mathrm{i}(1)$ & $\mathrm{j}(2)$ & $\operatorname{Nama}(3$ & & Mulai (ES) (5) & Selesai (EF) (6) & Mulai $(L S)(7)$ & Selesai (LF) (8) \\
\hline 1 & 2 & $a$ & 2 & 0 & 2 & 0 & 2 \\
\hline 2 & 3 & $b$ & 3 & 2 & 5 & 6 & 5 \\
\hline 2 & 4 & c & 5 & 2 & 7 & 2 & 7 \\
\hline 3 & 5 & d & 4 & 5 & 9 & 9 & 9 \\
\hline 4 & 5 & $\mathrm{e}$ & 6 & 7 & 13 & 7 & 13 \\
\hline 5 & 6 & $\mathrm{f}$ & 3 & 13 & 16 & 13 & 16 \\
\hline
\end{tabular}

From table 2. The countdown is information that is, the last start time of an activity can be done 13. The countdown is intended to know the time or the most recent date we "still" can start and end each activity without delaying the overall project completion period, which has resulted from forward pass.

\section{RESULT AND DISCUSSION}

\subsection{Use Case Diagram}

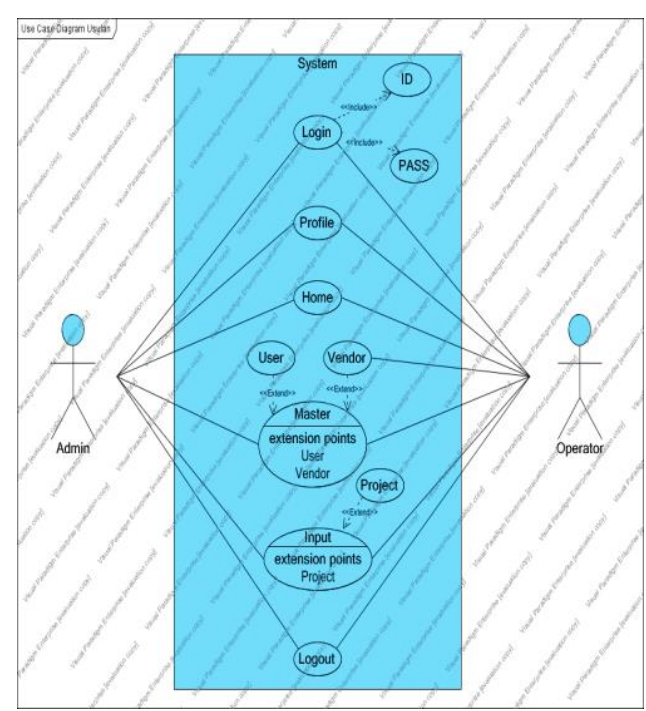

Figure 3. Use Case Diagram

\subsection{Result}

a. Login

Login form for admin and operator logins by entering the ID and password that already exists. After logging in, a home page will appear. 


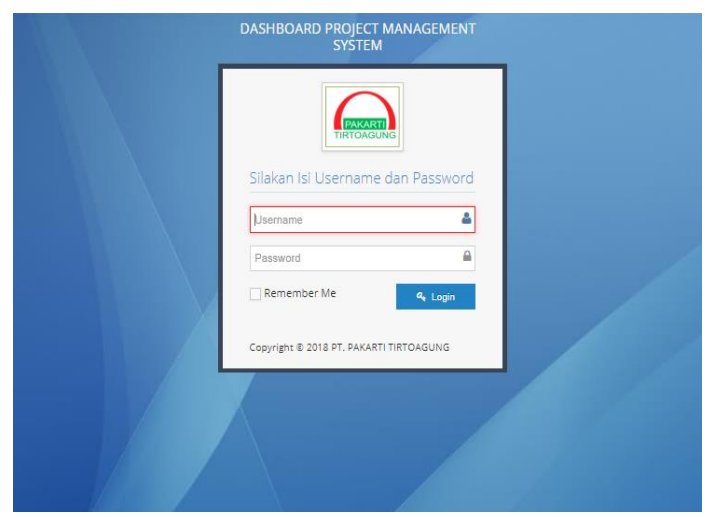

Figure 4. Login

\section{b. Home}

After the user has successfully logged in, a home page that contains information about the number of projects and the project value in the form of a pie chart appears. And there are the main menus namely profile, home, master in which there are sub menus namely user and vendor, input menu there is a project sub menu, and logout.

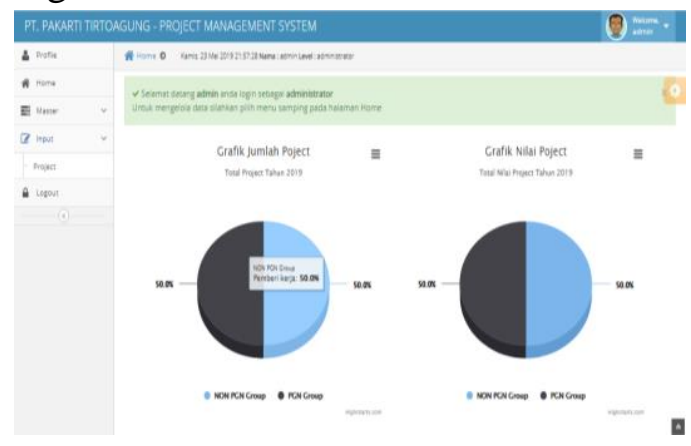

Figure 5. Home

\section{c. Project}

In the Input menu there is a project sub menu that contains information about the project list, and can perform several activities, namely create, update, print and can export reports in PDF format. The current project cannot be deleted. In the project list there is a function to see the project progress. And there are warnings about the project.

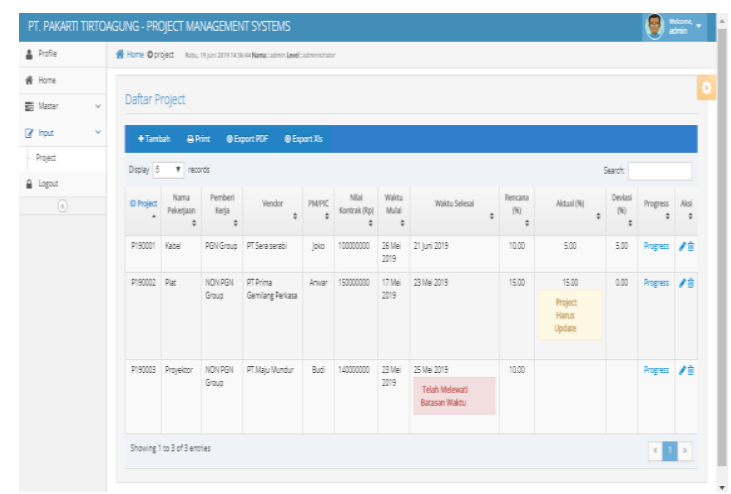

Figure 6. Project

\section{d. Add Progress}

Following is the display form added progress containing the project id, progress id, duration of progress, process description that shows the project activities, the process will automatically be filled in accordance with the order in which the process was inputted, act cost, and outstanding issues. Where the user can add progress when getting data from project workers regarding the development of the project.

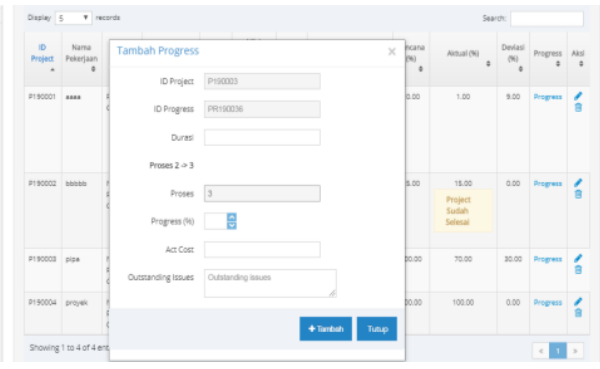

Figure 7. Add Progress

\section{e. Progress}

Users can see the progress of projects that are running by clicking the hyperlink in the project list table. Then a project progress display appears containing information about the project id, period, progress (\%), act cost, outstanding issues, and can perform several activities including 
creating, updating, deleting, printing progress reports, and being able to see a graph of project progress.

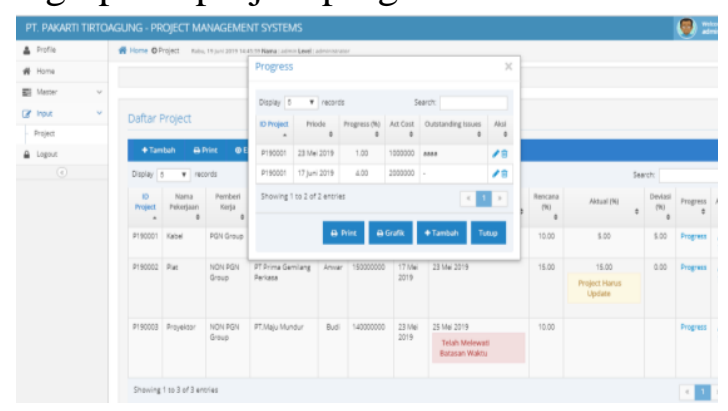

Figure 8. Progress

\section{f. Progress Report}

The following is a display of the project progress report / project progress which contains information about the project, project progress, up to the actual total development of the project along with the budget spent.

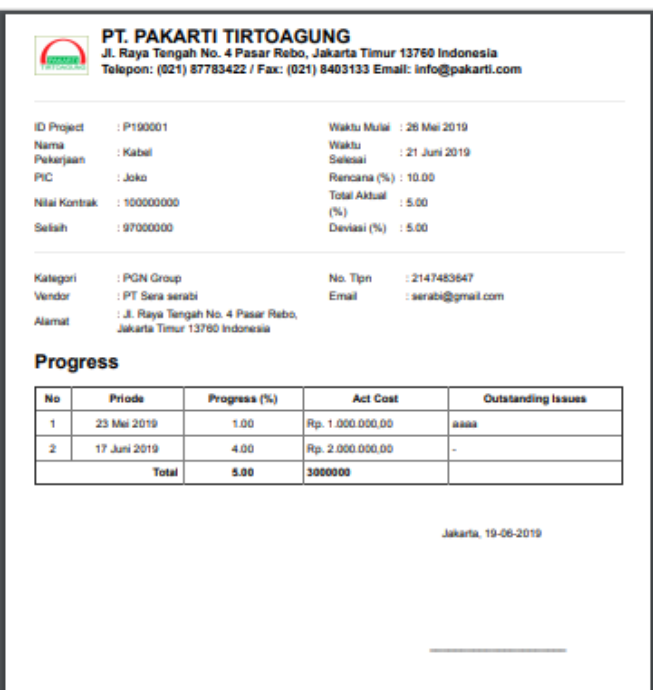

Figure 9. Progress Report

\section{g. Graphic Progress Report}

The project development graph display contains information about the project, the vendor, the actual total development of the project and adjusted for the budget that has been incurred.

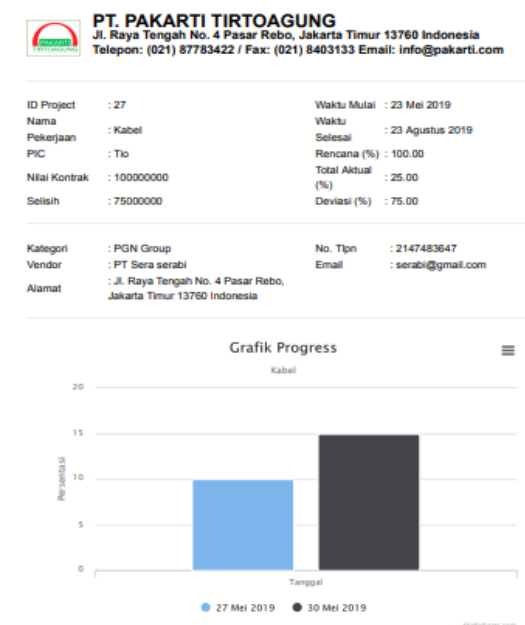

Figure 10. Graphic Progress Report

\subsection{Testing}

To find out whether the information system that has been designed can be useful and used by users or not, then the questionnaire was distributed as a medium for data collection. From the results of the questionnaire we can find out the responses of respondents to the information system that has been designed. One questionnaire sheet consists of 8 (eight) statements distributed to 10 (ten) respondents, with information SS = Sangat Setuju (5), $\mathrm{S}=$ Setuju (4), KS = Kurang Setuju(3), TS = Tidak Setuju (2). And got the following results:

Table 11. Percentage of Questionnaire

\begin{tabular}{|c|c|}
\hline \multicolumn{2}{|c|}{ Persentase } \\
\hline Jawaban & Persen $(\%)$ \\
\hline Sangat Setuju & $38 \%$ \\
\hline Setuju & $58 \%$ \\
\hline Kurang Setuju & $5 \%$ \\
\hline Tidak Setuju & $0 \%$ \\
\hline Total & $100 \%$ \\
\hline
\end{tabular}

From the above table it can be concluded that $58 \%$ of users agree and $38 \%$ of users strongly agree that the system can present information about the project. 


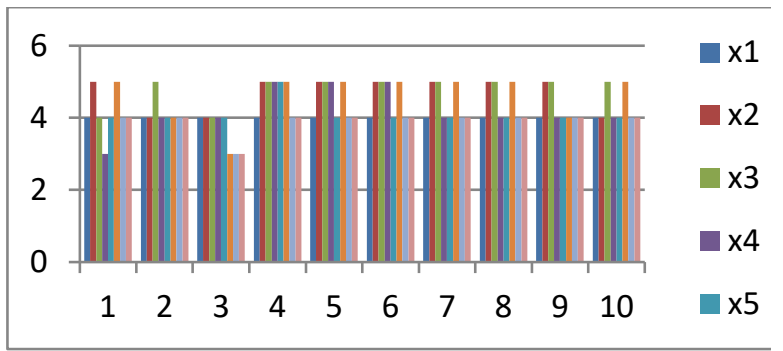

Figure 12. User Ease Graph

The graph above explains the level of ease of use of users in using the system which shows that the ease of managing project data, the system can help users in project implementation activities, project monitoring, and can help users in controlling the budgeting of the project, presents information on ongoing project progress along with actual costs. The higher the value, the better the system performance according to user ratings. Where the maximum value is 5, distributed to 10 respondents, with 8 statements.

\section{CONCLUSION}

\subsection{Conclusion}

Based on the results of the project management information system design using the CPM method at PT. Pakarti Tirtoagung, and based on the results of the questionnaire that was distributed to 10 (ten) respondents after being processed the result was $58 \%$ of respondents felt agreed and 38\% strongly agreed that the system could present information about the project, so the conclusion is:

4.
1. The system designed, can be used easily by the user and can present information about the ongoing project.

2. The system can assist users in carrying out project implementation activities to fit the plan.

3. The system can assist users in monitoring the project so that the project planning and implementation process can be monitored.

4. The system can help the user in controlling budgeting for the project being executed.

5. The system can present information about ongoing project progress along with actual costs.

\subsection{Suggestion}

The suggestions that will be delivered are expected to help to improve this system so that it will be better in the future, among others:

1. There is a development to increase the scope of the system in a broader direction so that the system becomes even more complex. For example, in terms of preparing project activity plans.

2. The addition of report print filters per period in accordance with company policy.

3. The graphic display in the program can be made more interesting and more informative, according to the tastes and needs of the user. 


\section{REFERENCES}

[1] Paramita, D. (2015). Rancang Bangun Sistem Informasi Kolaboratif Berbasis Web Untuk Manajemen Proyek Teknologi Informasi. Jurnal Buana Informatika, 196.

[2] Hamdan Dimyati, K. N. (2016). Manajemen Proyek. Pustaka Setia, 26.

[3] Simarmata, J. (2010). Rekayasa Web. Yogyakarta: Andi, 47.

[4] Andre. (2014, Desember 15). Tutorial Belajar PHP Part 1: Pengertian dan Fungsi PHP dalam Pemrograman Web. Dipetik Maret 8, 2019, dari Duniallkom: https://www.duniailkom.com/pengertian-dan-fungsi-php-dalam-pemograman-web/

[5] Raharjo B, d. (2012). Modul Pemrograman WEB (HTML, PHP, MySQL). Bandung: Modula, 216

[6] Ardian Riftha Dhuha, F. P., \& Priyambadha, B. (2017, November). Pengembangan Sistem Aplikasi Manajemen Proyek Berbasis Web (Studi Kasus: PT. Swadaya Graha). Jurnal Pengembangan Teknologi Informasi dan Ilmu Komputer, 1368.

[7] Waldi, B. S. (2016, Desember). ANALISA PENERAPAN MANAJEMEN WAKTU DAN BIAYA PADA PROYEK PEMBANGUNAN HOTEL BW LUXURY JAMBI. Jurnal Sains dan Teknologi Utama, 181-182.

[8] Karina Tika Aprilia, I. F. (2015). Estimasi biaya dan penjadwalan proyek konstruksi CV.IStomu menggunakan metode CPM. Prosiding seminar informatika aplikatif polinema, 173.

\section{BIOGRAPHY}

Edy Graduated from the Informatics Engineering Study Program (S1) at Gunadarma University, 2004, STMIK ERESHA Informatics Engineering Program, 2012. Currently as a permanent lecturer at the Faculty of Science and Technology, Buddhi Dharma University.

Felina Natalia Lie Graduated from the Information Systems Study Program (S1) in the Enterprise System, 2019. 